\title{
Earnings Management in the Pre and Post eXtensible Business Reporting Language Period in Indonesia
}

\author{
ARUNG GIHNA MAYAPADA* \\ MUHAMMAD AFDHAL \\ RAHMI SYAFITRI \\ Universitas Tadulako
}

\begin{abstract}
This study aims to determine and analyze the impact of XBRL adoption on earnings management conducted by company management in Indonesia. Earnings management in this study is proxied by discretionary accruals. The population of this research is manufacturing companies listed on the Indonesia Stock Exchange. The research sample was selected using the purposive sampling method, and the resulted total sample of this research is 15 manufacturing companies. This research period includes the period before the adoption of XBRL (2012-2014) and the period after the adoption of XBRL (2015-2017). Hypothesis testing is done by a paired sample t-test. The results of hypothesis testing indicate that there are significant differences between the levels of earnings management in the period before and after the adoption of XBRL. These results reveal that the adoption of XBRL can limit the opportunistic behavior of management in presenting financial reporting. These results also reveal that the adoption of XBRL can improve the quality of financial reporting.
\end{abstract}

Keywords: Earnings Management, Discretionary Accruals, Indonesia Stock Exchange, eXtensible Business Reporting Language.

Abstrak- Penelitian ini bertujuan untuk mengetahui dan menganalisis dampak pengadopsian XBRL terhadap manajemen laba yang dilakukan oleh manajemen perusahaan di Indonesia. Manajemen laba pada penelitian ini diproksikan oleh akrual diskresioner. Populasi penelitian ini adalah perusahaan manufaktur yang terdaftar di Bursa Efek Indonesia. Sampel penelitian ini dipilih menggunakan metode purposive sampling. Total sampel penelitian ini adalah 15 perusahaan manufaktur. Periode penelitian ini meliputi periode sebelum pengadopsian XBRL (2012-2014) dan periode setelah pengadopsian XBRL (2015-2017). Pengujian hipotesis dilakukan dengan uji $t$ sampel berpasangan. Hasil pengujian hipotesis menunjukkan bahwa terdapat perbedaan signifikan antara tingkat manajemen laba pada periode sebelum dan sesudah pengadopsian XBRL. Hasil ini mengungkap bahwa pengadopsian XBRL dapat membatasi perilaku oportunis manajemen dalam menyajikan pelaporan keuangan. Hasil ini juga mengungkap bahwa pengadopsian XBRL dapat meningkatkan kualitas pelaporan keuangan. 
Kata Kunci: Manajemen Laba, Akrual Diskresioner, Bursa Efek Indonesia, eXtensible Business Reporting Language.

\section{Introduction}

The quality of financial reporting is still a hot issue among academics and practitioners of accounting and business until after the 15-year of the Enron case. Various agendas have been released in order to improve the quality of financial reporting. Besides improving the quality of accounting standards and unifying accounting standards globally, the use of digital languages in financial reporting is also conducted to increase the usefulness of financial information (Baldwin et al., 2006). Financial information is useful if the financial information can meet the needs of its users. Therefore, digitizing financial reporting is the answer to the demands of the current big data era.

The use of digital language in financial reporting is not a new issue in financial reporting. Since 1999, the use of digital languages has been introduced in the business world called XBRL (eXtensible Business Reporting Language). At the beginning of its presence, the costs and benefits of XBRL were increasingly contested among academics and practitioners. Because the application of new technologies such as XBRL in financial reporting certainly requires expensive costs and a high risk of rejection. Even so, there are some companies considering the initial adoption of XBRL as a competitive advantage (Pinsker \& Li, 2008).

$\mathrm{XBRL}$ is a digital business reporting language standards developed to provide financial information to users that are utilized starting from the stages of preparation, presentation, and exchange of information (Boritz \& No, 2009). The XBRL in financial reporting helps firms prepare financial statements on time (Bovee et al., 2002; Cunningham, 2005). In addition, XBRL is able to meet various information needs of diverse users and increase the effectiveness and efficiency of the exchange of financial information between firms and stakeholders (Wills, 2005). The results of the study done by Dong et al. (2016) revealed that the use of XBRL, which makes financial reports machine-readable helps investors process different data more easily through various 
computer software. XBRL adoption can reduce the asymmetry of information that exists between management and external investors (Efendi et al., 2010; J. W. Kim et al., 2012; Tan \& Shon, 2009; Yoon et al., 2011). The external investor will get easier and accurate in analyzing the firm's financial information prepared in XBRL format because of easily accessible and comparable across firms (Baldwin \& Trinkle, 2011).

Several regulators have regulated XBRL mandatory adoption in a number of countries since 2008, such as India and the United States (Trites, 2010). Meanwhile, Indonesia has just started designing XBRL taxonomy in 2013. However, the taxonomy formulated by the Indonesia Stock Exchange received an acknowledgment status from XBRL International in 2014, so it is called Indonesia Stock Exchange (IDX) Taxo nomy 2014. All listed companies in Indonesia Stock Exchange have been required to submit XBRL-based financial reporting since August 2015 (Indonesia Stock Exchange, 2015). This phenomenon increases the studies of the issue regarding the mandatory adoption of XBRL, especially in Indonesia, which implemented XBRL in a short time (Zamroni \& Aryani, 2018).

Several previous studies have examined the impact of XBRL adoption on investor behavior as the primary user of financial information. However, it is still rare for studies to explicitly examine the impact of XBRL adoption on the behavior of financial reporting compilers, namely management (Kim et al., 2019). Though this issue was revealed by SEC Chairman Christopher Cox, who stated that the XBRL adoption by regulators could limit earnings management behavior of opportunist management (Alles \& Piechocki, 2012), therefore, this study aims to investigate the impact of XBRL adoption on earnings management done by management as the preparers of the financial statements.

The researchers examined manufacturing firms' earnings management practices in Indonesia. This study aims to fill the gap in empirical evidence from Indonesia since the mandatory use of XBRL in 2015. The results of this study can be a consideration for stock exchange regulators in Indonesia and other emerging markets like Indonesia 
in formulating policies related to business reporting of manufacturing firms. In the current big data era ${ }^{1}$.

This study is divided into five parts. The first part contains the study background. The second part is an explanation of XBRL, earnings management, and the hypothesis development for possible relationships between the two. Meanwhile, in the third part, we will explain the method used to test the hypothesis. Furthermore, the results of this study are discussed in the fourth part. Finally, the fifth section contains conclusions, limitations, and suggestions for the next research.

\section{Theoretical Framework and Hypothesis Development}

\subsection{Agency Theory}

Agency theory states that the relationship between management and shareholders, which is viewed as the relationship between agents and principals. Shareholders, as the principals, delegate authority to the management, as the agents, to use and control the firm's activities. As a result, management has more adequate information about the firm than shareholders. Information asymmetry between management and shareholders allows management to act opportunistically (Jensen \& Meckling, 1976). Management can act against the shareholders' interests while attempting to maximize their wealth (Shan \& Troshani, 2016). Management can manipulate financial and non-financial information related to the firm before it is conveyed to shareholders and stakeholders so that shareholders and stakeholders change their decisions.

In the context of agency theory, earnings management can be seen as an agency cost. Management can do earnings management because there is information asymmetry between management and stakeholders that allows

\footnotetext{
1, Big data are datasets whose size is beyond the ability of typical database software tools to capture, store, manage, and analyze (Franks, 2012).
} 
management to manipulate information reported to stakeholders, including earnings figures. Meanwhile, earnings figures are one of the primary considerations of stakeholders, especially investors, in assessing management's performance and in making investment decisions. Therefore, earnings management can lead to stakeholders wrong in assessing management performance and investment decision making, which can make stakeholders suffer losses.

\subsection{XBRL (eXtensible Business Reporting Language)}

XBRL (eXtensible Business Reporting Language) is an international standard for business reporting Digital based on XML (eXtensible Markup Language), which is developed by XBRL International. XBRL was initiated by Charles Hoffman, an American public accountant. In 1998, Charles Hoffman investigated the use of XML in the reporting of financial information electronically. Then, XBRL for financial statements was released in 2000. XBRL has been used by more than 100 regulators in more than 60 countries in the world today (XBRL, 2018).

Several advantages cause the rapid development of XBRL it has compared to other digital languages, namely HTML. XBRL can be used by anyone for free, without limitation, and publicly available. XBRL is also compatible with a wide range of hardware, operating system, and software exist (Cormier et al., 2018). The advantages of XBRL also make the exchange of business information between organizations going fast, accurate, effective, efficient, and digitalized well. Previously, the company was troubled by compiling business reports in various formats for each different user. XBRL facilitates business reporting by combining reporting formats that can be transmitted into any format according to the needs of various users.

XBRL works by making a " tag " sign that can be identified or known for each specific data. This "tag " can be easily read by a computer so that data can be identified in any language. This method makes it easier for stakeholders to obtain and process 
data electronically without the need to translate and re-input data. The data can be easily compared due to the same "tag" all over the world.

XBRL enhances the ability of users of financial statements to accessing and analyzing financial data (Kim et al., 2019). XBRL also facilitates users, especially prospective investors, in carrying out financial reporting analysis and comparison (IFRS Foundation, 2017). XBRL makes the preparation of the firm's financial reporting cheaper and faster for the firm itself (Debreceny \& Gray, 2001; Farewell, 2006).

The stages of XBRL adoption in Indonesia has been started since 2012. In 2013, the Indonesia Stock Exchange began formulating a special taxonomy for the firm's financial statements following the regulations and applicable financial accounting standards in Indonesia, as well as paying attention to the firm's characteristics in each sector and sub-sector of the industry. Furthermore, the IDX taxonomy that has been developed is used in preparing financial statements by firms listed on the Indonesia Stock Exchange in XBRL format since 2015. Even so, the Indonesia Stock Exchange continues to expand the XBRL taxonomy in order to improve information disclosure.

\subsection{Accrual Earnings Management}

Earnings management is an intervention in the external reporting process to obtain personal benefits conducted by management (Schipper, 1989). Basically, management is allowed to intervene in the financial reporting process. Management has the authority to determine the accounting techniques and policies that will be used in preparing the firm's financial statements.

Accounting standards that contain estimations, judgment, and accrual basis provide the opportunity for management to manipulate earnings numbers (Harahap, 2011). Estimated bad debts, inventory valuation, methods, and estimations related to the depreciation of fixed assets can change the earnings number. In addition, the accrual basis which requires firms to recognize revenue (expense) even cash is not received (paid). Therefore, earnings management done by utilizing loopholes in applicable accounting standards is also called accrual earnings management (Sohn, 2016). 
When accrual earnings management misleads and harms external investors, the investors have the right to take action against management by changing management through an annual meeting of shareholders. However, accrual earnings management is difficult to be detected by external investors. According to the result of the previous study, the more accounting information can be compared, the lower the magnitude of earnings management (Sohn, 2016). Investors detect accrual earnings management more easily by comparing financial statements between different firms, which are presented the financial statements in the same format.

\subsection{Hypothesis Development}

The study of XBRL has been done since its inception, especially regarding the costs and benefits of XBRL adoption. However, the study of the relationship between XBRL adoption and earnings management is scarce. Even so, the results of the previous study regarding XBRL have revealed that there is a possibility of a strategic relationship between XBRL adoption and earnings quality (Cormier et al., 2018).

The previous studies revealed that XBRL adoption could reduce information asymmetry in several capital markets in the world (Chen \& Li, 2013; Efendi et al., 2010; Kim et al., 2012; Tan \& Shon, 2009; Yoon et al., 2011). The XBRL adoption had an impact on the increasing accessibility of firm financial information by various users, including investors (Kim et al., 2019; Kim et al., 2012). XBRL also helps investors process and analyze financial information because they can process the desired data directly into analysis software (Baldwin \& Trinkle, 2011; Efendi et al., 2014). Hodge et al. (2004) and Pinsker \& Wheeler (2009) found that investors who use existing technology well, such as XBRL, are better to interpret the information contained in financial statements than investors who do not use the technology. The previous studies found that XBRL adoption increases the transparency of firm financial statements (Bai et al., 2014; Kim et al., 2019; Kim et al., 2012; Pinsker \& Li, 2008; Wang \& Seng, 2014; Yen \& Wang, 2015; Yoon et al., 2011).

XBRL, through the tagging process organized in a taxonomy, makes the process of collecting data and preparing financial statements more efficient and effective. The 
compilers of financial statements that previously had to be made in some different formats according to user requirements become only made in one XBRL format that can be changed easily and quickly into various other formats. Tagging and automation of XBRL in producing financial statements also makes it difficult for management to manipulate financial statements (Baldwin \& Trinkle, 2011). Management cannot make different financial statements for different needs because the financial statements have been prepared using XBRL, which later through these formats will be changed in various formats.

Meanwhile, other previous studies revealed that the lower the information asymmetry, the lower the level of earnings management carried out by management (Bhattacharya et al., 2013; Chaney \& Lewis, 1995; Jayaraman, 2008; Rajgopal \& Venkatachalam, 2011). The better information obtained by external investors creates opportunities for management to behavior opportunistically by manipulating firm information increasingly limited (Schipper, 1989). Also, the transparency of information makes external investors better able to mitigate management incentives to manipulate earnings (Cohen et al., 2008; Huang \& Zhang, 2012). The previous study has revealed that the transparency of financial reporting can reduce earnings management ( $\mathrm{Li}, 2018)$.

Based on the results of previous studies on the above, the XBRL adoption can minimize the chance of management to do earnings management because the information is owned by externals approximately equal in quality to those owned by management. (Boritz \& No, 2009) revealed that the use of extension avoids investors from lack of information and improves financial reporting quality. Kim et al. (2019) revealed that the magnitude of accrual earnings management in firms had decreased significantly from the period before the XBRL adoption to the period after the XBRL adoption explicitly. Therefore, we suggest that:

H1: There is a significant difference in the magnitude of firm earnings management between the period before the mandatory adoption of XBRL and the period after the mandatory adoption of XBRL. 


\section{Research Method}

\subsection{Population and Sample}

The population of this study includes all manufacturing firms listed on the Indonesia Stock Exchange. Because the majority of firms listed on the Indonesia Stock Exchange are engaged in the manufacturing industry sector. Therefore, manufacturing firms are considered to represent of the Indonesia Stock Exchange precisely. The period of this study is from 2012 to 2017. The adoption of IFRS in Indonesia has been carried out since 2012, so that the period of this study starts in 2012. In addition, based on the press release of Indonesia Stock Exchange No. 013/BEI-SPR/06-2015, the mandatory adoption of XBRL for all listed companies in Indonesia Stock Exchange took place starting in August 2015. Therefore, this study divides the period into the period before the XBRL adoption (2012-2014) and the period after the XBRL adoption (2015-2017). The total population of this study is 133 companies. The sampling technique of this study used is a purposive sampling method with the criteria of firms that have never suffered losses during the study period, using the rupiah currency, and the firm's financial statements ended on December 31. These criteria are considered in the selection of samples to control for other factors that can affect the magnitude of earnings management in Indonesia, precisely the essential characteristics of the firms (Peng et al., 2011). The total sample is 15 manufacturing firms.

\subsection{Variable Measuring}

The existence of earnings management is generally proxied through discretionary accruals, also known as abnormal accruals (Jones et al., 2007). Several models can be used to calculate the discretionary accruals, which have been developed as the proxy of earnings management. However, this study uses a model developed by Jones modified by Dechow et al. (1995) in calculating the discretionary accruals. Because the model is the best in detecting earnings management (Dechow et al., 1995).

Determining discretionary accruals as a proxy of earnings management based on the Jones modified by Dechow et al. (1995) can be described as follows:

$\mathrm{TAC}=\mathrm{Nit}-\mathrm{CFO}$ it 
The value of total accruals (TA) is estimated by the OLS regression equation as follows:

TAit/Ait-1 $=\beta 1(1 /$ Ait-1 $)+\beta 2(\Delta$ Revit/Ait-1 $)+\beta 3($ PPEt/Ait-1 $)+e$

Using the regression coefficient above the value of non-discretionary accruals (NDA) can be calculated using the formula:

NDAit $=\beta 1(1 /$ Ait-1 $)+\beta 2(\Delta$ Revit $/$ Ait-1- $\Delta$ ARit/Ait-1 $)+\beta 3($ PPEit/Ait-1 $)$

Next, discretionary accruals (DA) can be calculated as follows:

DAit $=($ TAit $/$ Ait -1$)-$ NDAit

Notes:

DAit $=$ Discretionary Accruals of a company $\mathrm{i}$ in period $\mathrm{t}$

NDAit $=$ Non-Discretionary Accruals of a company $i$ in period $t$

TAit $=$ Total accruals of a company $\mathrm{i}$ in period $\mathrm{t}$

Nit $=$ Net income of company $\mathrm{i}$ in period $\mathrm{t}$

CFOit $=$ Cash flow operation of a company $\mathrm{i}$ in period $\mathrm{t}$

Ait-1 = Total assets of a company $\mathrm{i}$ in period $\mathrm{t}-1$

$\Delta$ Revt $=$ The change of revenue of company $\mathrm{i}$ in period $\mathrm{t}$

PPEt $=$ The PPE assets of a company $\mathrm{i}$ in period $\mathrm{t}$

$\Delta$ Rect $=$ The change of account receivable of a company $\mathrm{i}$ in period $\mathrm{t}$

$\mathrm{e} \quad=$ error

The researchers choose to use the absolute value of the discretionary accrual as a proxy for earnings management because the researchers only focus on managing earnings in general. Researchers do not distinguish whether earnings management is carried out to increase or decrease earnings figures. The higher the value of absolute discretionary accruals, the higher the magnitude of earnings management by the firm. Conversely, the closer to zero the value of absolute discretionary accruals, the lower the magnitude of earnings management by the firm.

\subsection{Data Analysis Method}

The data analysis method used in this study is a univariate analysis through paired sample t-test. The paired sample t-test has been selected for this study because this study 
aims to investigate whether there are significant differences in the magnitude of earnings management in the period before and after the mandatory adoption of XBRL.

\section{Results and Discussion}

\subsection{Descriptive Statistics Analysis}

The descriptive statistics of the research data are shown in Table 1 as follows.

Table 1.

Descriptive Statistics

\begin{tabular}{|l|r|r|r|r|r|r|}
\hline & $\mathrm{N}$ & Range & Minimum & Maximum & Mean & Std. Deviation \\
\hline PREXBRL & 45 & .35 & .00 & .35 & .0909 & .07172 \\
\hline POSTXBRL & 45 & .14 & .00 & .14 & .0426 & .03312 \\
\hline Valid N (listwise) & 45 & & & & & \\
\hline
\end{tabular}

Table 1 shows the characteristics of the research data, including range, minimum, maximum, mean, and standard deviation. There are 45 observation data for absolute discretionary accruals as a proxy of earnings management pre-XBRL adoption (PREXBRL) and also 45 observation data for absolute discretionary accruals as a proxy of earnings management post-XBRL adoption (POSTXBRL). Based on Table 1, the maximum value of PREXBRL data is 0.35, which is Lionmesh Prima Tbk in 2012. The maximum value of POSTXBRL data is 0.14 , which is Mayora Indah Tbk in 2016. The mean value of absolute discretionary accruals in PREXBRL is 0.0909, which is larger than the mean value of absolute discretionary accruals in POSTXBRL 0.0426. The value of the standard deviation of PREXBRL (0.07172) and POSTXBRL (0.03312) is low, which means that the average distance of each unit of data is low to the mean value. The difference of the mean value of absolute discretionary accruals between PREXBRL and POSTXBRL is hypothesized caused by the XBRL adoption in the financial reporting of all listed manufacturing companies in the Indonesia Stock Exchange.

Before testing the hypothesis, researchers screen data normality so that statistical test results will be better. Non-parametric statistics do screening the normality of data by the Kolmogorov-Smirnov (K-S) test. The first test results show that the data is not 
normally distributed. The data is then transformed to become normal in the form of SQRT transformation. After being transformed, the research data in the form of SQRT are normally distributed as the results in table 2 .

Table 2.

The Result of One-Sample Kolmogorov Smirnov Test

One-Sample Kolmogorov-Smirnov Test

\begin{tabular}{|l|l|r|r|}
\hline \multicolumn{2}{|c|}{} & $\begin{array}{c}\text { SQRTAbsDA } \\
\text { PreXBRL }\end{array}$ & $\begin{array}{c}\text { SQRTAbsDA } \\
\text { PostXBRL }\end{array}$ \\
\hline N & 45 & 45 \\
\hline \multirow{2}{*}{ Normal Parameters } & Mean &, 2791 &, 1896 \\
\cline { 2 - 4 } & Std. Deviation &, 11542 &, 08244 \\
\hline \multirow{2}{*}{ Most Extreme Differences } & Absolute &, 096 &, 101 \\
\cline { 2 - 5 } & Positive &, 096 &, 101 \\
\cline { 2 - 5 } & Negative &,- 069 &,- 078 \\
\hline \multicolumn{2}{|l|}{ Test Statistic } &, 096 &, 101 \\
\hline Asymp. Sig. (2-tailed) &, 200 &, 200 \\
\hline
\end{tabular}

\subsection{The Results of Hypothesis Testing and Discussions}

The result of the paired sample t-test is shown in Table 3. Table 3 shows that the value of significance (2-tailed) is 0.000 , which is lower than the $\alpha$ value of 0.05 . Table 3 shows that the t-value at 0.05 is 4.730 , which is higher than the t-table 2.4109. This result means that there is a significant difference between the magnitude of earnings management in the pre-XBRL period and the post-XBRL period. Table 3 also shows that the mean value of earnings management in the pre-XBRL period is higher than the mean value of earnings management in the post-XBRL period statistically. This result shows that the magnitude of earnings management decreases significantly after XBRL mandatory adoption. This result is in line with the result of (Kim et al., 2019; Peng et al., 2011).

This result means that XBRL adoption can limit the earnings management behavior of management. After the adoption of XBRL in the preparation of financial statements, management was less able to manage earnings figures in general. It means that the financial statements produced in the XBRL format more faithfully represent the existing conditions due to minimal management intervention. 
Table 3.

The Results of The Hypothesis Testing

Paired Samples Statistics

\begin{tabular}{|c|c|c|c|c|c|}
\hline & & Mean & $\mathrm{N}$ & Std. Deviation & Std. Mean Error \\
\hline \multirow{2}{*}{ Pair 1 } & SQRTAbsDAPREXBRL & .2791 & 45 & .11542 & .01721 \\
\cline { 2 - 6 } & SQRTAbsDAPOSTXBRL & .1896 & 45 & .08244 & .01229 \\
\hline
\end{tabular}

Paired Samples Test

\begin{tabular}{|r|c|c|c|c|c|}
\hline \multirow{2}{*}{} & \multicolumn{3}{|c|}{ Paired Differences } & \multicolumn{2}{|c|}{} \\
\cline { 2 - 7 } & \multicolumn{2}{|c|}{$\begin{array}{c}\text { 95\% Confidence } \\
\text { Interval of the } \\
\text { Difference }\end{array}$} & \multicolumn{2}{|c|}{} \\
\cline { 2 - 7 } & Lower & Upper & t & Df & Sig. (2-tailed) \\
\cline { 2 - 7 } Pair 1 SQRTAbsDAPREXBRL - & .05138 & .12768 & 4.730 & 44 & .000 \\
SQRTAbsDAPOSTXBRL & & & & & \\
\hline
\end{tabular}

XBRL adoption increases the transparency and comparability of financial statements. The use of XBRL as a disclosure tool reduces the potential for the disparity between firms in terms of the level of disclosure and content (Premuroso \& Bhattacharya, 2008). According to Kim et al. (2019), the use of standardized XBRL tagging in a taxonomy significantly reduces the magnitude of discretionary accruals. XBRL increases the accessibility, timeliness, and comparability of financial statements. The production of financial statements through XBRL is faster and more precise because XBRL can be integrated with existing accounting software, can be changed in various formats required by the various users, and has an integrated format in a taxonomy that is mandated to all firms in a capital market (Baldwin \& Trinkle, 2011; Kim et al., 2019). Increasing the transparency of financial statements will make it easier for external investors and other stakeholders to understand the firm's economic performance and detect abnormal accrual choices. In addition, the transparency of financial statements also makes it easier for external investors to supervise management behavior. Effective oversight by external investors results in information asymmetry between management and outside investors that triggers management's earnings management behavior declines. So, outside investors become more precise and faster 
in making economic decisions. This condition has an impact on increasing the litigation risk faced by management. Therefore, management will avoid doing earnings management to secure its position.

\section{Conclusion, Implication, and Limitation}

\subsection{Conclusion}

This study has revealed that the adoption of the latest information technology in preparing financial reporting impacts on changes in the behavior of financial reporting compilers which is management. The adoption of XBRL has been proven empirically can mitigate earnings management carried out by management with increasing transparency and comparability of financial reporting between firms. However, the more transparency of financial statements does not mean eliminating earnings manage ment because management can do other methods of managing earnings figures to avoid being seen by investors. Therefore, further research on this issue needs to be carried out in order to improve the quality of financial reporting in the big data era.

\subsection{Implication and Limitation}

Our finding offers evidence supporting the business case of XBRL adoption in Indonesia, where XBRL has been mandated. Also, Indonesia is an emerging economy, so that our findings may be generalized to other similar emerging economies in the world. Moreover, the study on the issue of XBRL and earnings management is still rarely done based on the best of researchers' knowledge.

This study has important implications for regulators and manufacturing firms. For regulators, the results of this study imply that the implementation of XBRL needs to be improved in order to increase the transparency of financial reporting and minimize fraud by management, which will ultimately have an impact on increasing investment in the country. Besides, regulators should also use XBRL in order to improve the quality of financial reporting through the formulation of XBRL taxonomies based on the needs of users and compilers. 
Meanwhile, the result of this study also has significant implications for manufacturing firms to increase compliance in the use of XBRL when preparing financial statements. The use of XBRL not only streamlines the process of preparing financial reporting but also improves the quality and transparency of corporate financial reporting, which has an impact on increasing the attention of potential investors.

Lastly, the finding of this study has a significant impact on improving the quality of financial reporting, in which the implementation of XBRL can minimize the level of earnings management. As a result, the transparency and quality of financial reporting increases, thereby increasing investor confidence in the capital market. Increased investment will have an impact on improving the national economy, especially in developing countries like Indonesia (Shan \& Troshani, 2016).

This study has several limitations so that the interpretation of the result of this study should be made carefully. First, this study only provides empirical evidence from the Indonesian capital market. As a result, the generalization of the result of this study on the capital markets outside Indonesia must be carried out carefully because there are characteristics of the capital market that distinguish between countries. Therefore, further studies can expand the population by adding other countries' capital markets. Second, the period of this study only covered six years due to the adoption of XBRL in Indonesia, which had only begun three years ago. The next researcher can extend the research period so that the research findings are more comprehensive. Third, this study only uses one accrual earnings management proxy. Future studies can use other proxies from accrual earnings management to find more comprehensive results and verify the findings of previous studies. Fourth, this result indicates that a decrease in earnings management could be attributed to other variables, including changes in firm fundamentals and the firm's characteristics (Peng et al., 2011). The next researchers can add the controlling variables. 


\section{References}

Alles, M., \& Piechocki, M. (2012). Will XBRL improve corporate governance? International Journal of Accounting Information Systems, 13(2), 91-108. https://doi.org/10.1016/j.accinf.2010.09.008

Bai, Z., Sakaue, M., \& Takeda, F. (2014). The Impact of XBRL Adoption on the Information Environment: Evidence from Japan. The Japanese Accounting Review, 4(2014), 49-74. https://doi.org/10.11640/tjar.4.2014.03

Baldwin, A. A., Brown, C. E., \& Trinkle, B. S. (2006). XBRL: An Impacts Framework and Research Challenge. Journal of Emerging Technologies in Accounting, 3(1), 97-116. https://doi.org/10.2308/jeta.2006.3.1.97

Baldwin, A. A., \& Trinkle, B. S. (2011). The Impact of XBRL: A Delphi Investigation. The International Journal of Digital Accounting Research, 11. https://doi.org/10.4192/1577-8517-v11_1

Bhattacharya, N., Desai, H., \& Venkataraman, K. (2013). Does Earnings Quality Affect Information Asymmetry? Evidence from Trading Costs Earnings Quality and Information Asymmetry. Contemporary Accounting Research, 30(2), 482-516. https://doi.org/10.1111/j.1911-3846.2012.01161.x

Boritz, J. E., \& No, W. G. (2009). Assurance on XBRL-Related Documents: The Case of United Technologies Corporation. Journal of Information Systems, 23(2), 49-78. https://doi.org/10.2308/jis.2009.23.2.49

Bovee, M., Ettredge, M. L., Srivastava, R. P., \& Vasarhelyi, M. A. (2002). Does the Year 2000 XBRL Taxonomy Accommodate Current Business Financial-Reporting Practice? Journal of Information Systems, 16(2), 165-182. https://doi.org/10.2308/jis.2002.16.2.165

Chaney, P. K., \& Lewis, C. M. (1995). Earnings management and firm valuation under asymmetric information. Journal of Corporate Finance, 1(3-4), 319-345. https://doi.org/10.1016/0929-1199(94)00008-I

Chen, H., \& Li, F. (2013). Analysis of the Impact of XBRL in China's Capital Market Using Methods of Empirical Research. Research Journal of Applied Sciences, Engineering, and Technology, 5(5), 1521-1527.

Cohen, D. A., Dey, A., \& Lys, T. Z. (2008). Real and Accrual-Based Earnings Management in the Pre- and Post-Sarbanes-Oxley Periods. The Accounting Review, 83(3), 757-787. https://doi.org/10.2308/accr.2008.83.3.757

Cormier, D., Dufour, D., Luu, P., Teller, P., \& Teller, R. (2018). The Relevance of XBRL Voluntary Disclosure for Stock Market Valuation: The Role of Corporate Governance: The Relevance of XBRL. Canadian Journal of Administrative Sciences / Revue Canadienne Des Sciences de l'Administration. https://doi.org/10.1002/cjas.1483 
Cunningham, C. S. (2005). XBRL: A Multitalented Tool. Journal of Accountancy, 199(4), 7071.

Debreceny, R., \& Gray, G. L. (2001). The production and use of semantically rich accounting reports on the Internet: XML and XBRL. International Journal of Accounting Information Systems, 2(1), 47-74. https://doi.org/10.1016/S1467-0895(00)00012-9

Dechow, P. M., Sloan, R. G., \& Amy, P. (1995). Detecting Earnings Management. The Accounting Review, 70(2), 193-225.

Dong, Y., Li, O. Z., Lin, Y., \& Ni, C. (2016). Does Information-Processing Cost Affect FirmSpecific Information Acquisition? Evidence from XBRL Adoption. Journal of Financial and Quantitative Analysis, 51(02), 435-462. https://doi.org/10.1017/S0022109016000235

Efendi, J., Park, J. D., \& Smith, L. M. (2014). Do XBRL filings enhance informational efficiency? Early evidence from post-earnings announcement drift. Journal of Business Research, 67(6), 1099-1105. https://doi.org/10.1016/j.jbusres.2013.05.051

Efendi, J., Park, J. D., \& Subramaniam, C. (2010). Do XBRL Reports Have Incremental Information Content? - An Empirical Analysis. SSRN Electronic Journal. https://doi.org/10.2139/ssrn.1671723

Farewell, S. M. (2006). An Introduction to XBRL through the Use of Research and Technical Assignments. Journal of Information Systems, 20(1), 161-185. https://doi.org/10.2308/jis.2006.20.1.161

Franks, B. (2012). Taming the big data tidal wave: Finding opportunities in huge data streams with advanced analytics. Wiley.

Harahap, S. S. (2011). Teori Akuntansi (Edisi Revisi). Rajawali Press.

Hodge, F. D., Kennedy, J. J., \& Maines, L. A. (2004). Does Search-Facilitating Technology Improve the Transparency of Financial Reporting? The Accounting Review, 79(3), 687703. https://doi.org/10.2308/accr.2004.79.3.687

Huang, Y., \& Zhang, G. (2012). An Examination of the Incremental Usefulness of BalanceSheet Information Beyond Earnings in Explaining Stock Returns. Journal of Accounting, Auditing \& Finance, 27(2), 267-293. https://doi.org/10.1177/0148558X11409153

IFRS Foundation. (2017). Conceptual Framework for Financial Reporting. London: IFRS Foundation.

Jayaraman, S. (2008). Earnings Volatility, Cash Flow Volatility, and Informed Trading. Journal of Accounting Research, 46(4), 809-851. https://doi.org/10.1111/j.1475679X.2008.00293.x 
Jensen, M. C., \& Meckling, W. H. (1976). Theory of the firm: Managerial behavior, agency costs, and ownership structure. Journal of Financial Economics, 3(4), 305-360. https://doi.org/10.1016/0304-405X(76)90026-X

Jones, K., Krishnan, G. V., \& Malenderez, K. (2007). Do Models of Discretionary Accruals Detect Actual Cases of Fraudulent and Restated Earnings? An Empirical Evaluation. Working Papers, George Mason University \& New Mexico State University.

Kim, J., Kim, J. W., \& Lim, J. (2019). Does XBRL Adoption Constrain Earnings Management? Early Evidence from Mandated U.S. Filers. Contemporary Accounting Research, 36(4), 2610-2634. https://doi.org/10.1111/1911-3846.12493

Kim, J. W., Lim, J.-H., \& No, W. G. (2012). The Effect of First Wave Mandatory XBRL Reporting across the Financial Information Environment. Journal of Information Systems, 26(1), 127-153. https://doi.org/10.2308/isys-10260

Li, Y.-Y. (2018). Information Transparency and Earnings Management-Evidence from Chinars Multi-Tiered Capital Market System. Proceedings of the 4th Annual International Conference on Management, Economics, and Social Development (ICMESD 2018). 4th Annual International Conference on Management, Economics, and Social Development (ICMESD 2018), Xi'an, China. https://doi.org/10.2991/icmesd-18.2018.1

Peng, E. Y., Shon, J., \& Tan, C. (2011). XBRL and Accruals: Empirical Evidence from China: XBRL AND ACCRUALS: EMPIRICAL EVIDENCE FROM CHINA. Accounting Perspectives, 10(2), 109-138. https://doi.org/10.1111/j.1911-3838.2011.00021.x

Pinsker, R., \& Li, S. (2008). Costs and Benefits of XBRL Adoption: Early Evidence. Communication of the ACM, 51(3), 47-50.

Pinsker, R., \& Wheeler, P. (2009). Nonprofessional investors' perceptions of the efficiency and effectiveness of XBRL-enabled financial statement analysis and of firms providing XBRL-formatted information. International Journal of Disclosure and Governance, 6(3), 241-261. https://doi.org/10.1057/jdg.2009.6

Premuroso, R. F., \& Bhattacharya, S. (2008). Do early and voluntary filers of financial information in XBRL format signal superior corporate governance and operating performance? International Journal of Accounting Information Systems, 9(1), 1-20. https://doi.org/10.1016/j.accinf.2008.01.002

Rajgopal, S., \& Venkatachalam, M. (2011). Financial reporting quality and idiosyncratic return volatility. Journal of Accounting and Economics, 51(1-2), 1-20. https://doi.org/10.1016/j.jacceco.2010.06.001

Schipper, K. (1989). Earnings Management. Accounting Horizons, 3(4), 91-102.

Shan, Y. G. \& Troshani, I. (2016). The effect of mandatory XBRL and IFRS adoption on audit fees: Evidence from the Shanghai Stock Exchange. International Journal of Managerial Finance, 12(2), 109-135. 
Sohn, B. C. (2016). The effect of accounting comparability on the accrual-based and real earnings management. Journal of Accounting and Public Policy, 35(5), 513-539. https://doi.org/10.1016/j.jaccpubpol.2016.06.003

Tan, C., \& Shon, J. (2009). XBRL and Its Financial Reporting Benefits: Capital Market Evidence. The International Conference at The University of Kansas, Lawrence.

Trites, G. (2010). Discussion of 'Assurance on XBRL Instance Document: A Conceptual Framework of Assertions.' International Journal of Accounting Information Systems, 11(3), 279-281. https://doi.org/10.1016/j.accinf.2010.07.021

Wang, T., \& Seng, J.-L. (2014). Mandatory Adoption of XBRL and Foreign Institutional Investors' Holdings: Evidence from China. Journal of Information Systems, 28(2), $127-$ 147. https://doi.org/10.2308/isys-50789

Wills, M. (2005). XBRL and Data Standardization: Transforming the Way CPAs Work. Journal of Accountancy, 199(3), 80-81.

Yen, J.-C., \& Wang, T. (2015). The Association between XBRL Adoption and Market Reactions to Earnings Surprises. Journal of Information Systems, 29(3), 51-71. https://doi.org/10.2308/isys-51039

Yoon, H., Zo, H., \& Ciganek, A. P. (2011). Does XBRL adoption reduce information asymmetry? Journal of Business Research, 64(2), 157-163. https://doi.org/10.1016/j.jbusres.2010.01.008

Zamroni, M., \& Aryani, Y. A. (2018). Initial Effects of Mandatory XBRL Adoption Across The Indonesia Stock Exchange's Financial Information Environment. Jurnal Keuangan Dan Perbankan, 22(2), 181-197. 
The Indonesian Journal of Accounting Research - Jan, Vol. 23, No.1, 2020

intentionally blank 